\title{
III PREMIO JOSÉ MANUEL ESTEVE
}

\section{Acta de constitución y fallo del jurado}

Reunido en la Facultad de Ciencias de la Educación de la Universidad de Málaga el Jurado de la tercera edición del Premio José Manuel Esteve compuesto por:

Presidente:

- Don José Francisco Murillo Mas, Decano de la Facultad de Ciencias de la Educación de la Universidad de Málaga.

Vocales:

- Doña Dolores Alcántara Sacristán, representante del Departamento de Didáctica y Organización Escolar de esta Facultad.

- Don Iván Fernández López, representante elegido por la Junta de Centro.

- Don Fernando Gil Cantero, ganador del II Premio José Manuel Esteve de la Universidad Complutense de Madrid.

\section{Secretaria:}

- Doña Carmen Sanchidrián Blanco, representante del Departamento de Teoría e Historia de la Educación.

El jurado, en nombre de la Facultad de Ciencias de la Educación de la Universidad de Málaga, quiere agradecer la acogida que ha tenido esta convocatoria a la que se han presentado artículos publicados en importantes revistas de muchos países.

El fallo del jurado ha sido difícil por la calidad académica de los artículos presentados. Finalmente, se ha acordado, por unanimidad, conceder el III PREMIO JOSÉ MANUEL ESTEVE a Don Antonio Viñao Frago, por su artículo "Del garabato y los palotes a la escritura: notas sobre la génesis y el concepto de preescritura", publicado en la revista History of Education \& Children's Literature . 2012, Vol. 7-1, pp. 45-68. El jurado ha acordado la concesión del premio a este artículo por la importancia y originalidad del tema tratado así como por el tratamiento riguroso que se le da. Este trabajo aborda los diversos orígenes y la diversidad de ideas, propuestas y actividades comprendidas en el concepto de preescritura, un producto de la cultura escolar desarrollado en el último cuarto del siglo XIX, pero especialmente en la primera mitad del XX. Se estudian, entre otros aspectos, los debates suscitados acerca de la enseñanza de la escritura, la difusión del método global y la disociación entre la enseñanza de la escritura y la de la caligrafía en la escuela en un período en el que la educación infantil se extendió y consolidó como nivel educativo.

Lo que firmo como secretaria en Málaga, a 19 de diciembre de 2013.

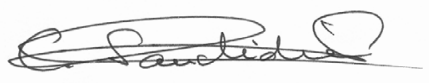

